\section{Species-specific climate response of oaks (Quercus spp.) under identical environmental conditions}

\author{
Tanja GM Sanders ${ }^{(1-2)}$, Rona Pitman ${ }^{(3)}$, Mark SJ Broadmeadow ${ }^{(3-4)}$
}

Oak forests play a major role in Britain due to their economic, social and historic value. Sudden oak death and general decline symptoms have therefore caused major concerns in the forestry sector over the past decade. Several strategies have been proposed to preserve the economic and social value of oak forests, including the planting of native species with more southerly origins, or non-native species of oak that may be better suited to the projected climate of the future. The Ovington research plots, established 50 years ago at the Bedgebury Pinetum in southeast England, provided the opportunity to compare annual growth rates and climate-growth relationships of five oak species growing adjacent to each other on the same soil type and under the same climatic conditions. Clear differences were evident in annual increment and climate-growth responses for the five Quercus species. Growth rates were significantly lower $(p<0.05)$ for the two species native to the UK $(Q$. petraea and $Q$. robur) compared to the southern European and American species. A partitioning analysis using key climatic variables separates $Q$. coccinea from the other species due to its negative response to low temperatures. These results were confirmed by pointer year analysis. The analysis suggests that $Q$. robur is likely to be the more resilient of the two native species of oak to the future climate of southern Britain. Of the non-native species of oak evaluated, $Q$. coccinea represents an alternative species to $Q$. robur and $Q$. petraea on very dry, nutrient-poor sites. Q. palustris may also have some potential under current conditions for species diversification, but its requirement for higher summer precipitation than the other four species suggests that this potential may not be sustained as climate change progresses. However, if alternative species are selected as more resilient to climate change in terms of growth, it will be essential to consider a range of other issues including impacts on biodiversity, resilience to endemic tree pests and diseases, form and appearance, landscape and timber quality.

Keywords: Quercus spp., Species Trial, Dendroecology, Climate-growth Relationships

\section{Introduction}

An increase in pest and disease outbreaks as well as projected climate warming constitutes a serious threat to forestry over the coming decades (Bolte et al. 2009, Sturrock et al. 2011). As a consequence of these impacts, individually or in combination, tree vitality and survival may decline resulting in reduced productivity (Leuzinger et al. 2005). The resilience of species to biotic and abiotic stresses, as well as their adaptation potential to changing environmental conditions, is important knowledge to guide sustainable forest management (Arend et al. 2011). Oak

$\square$ (1) Thünen-Institute of Forest Ecosystems, Alfred-Moeller-Str. 1, D-16225 Eberswalde (Germany); (2) Institute for Botany and Landscape Ecology, University Greifswald, Grimmer Str. 88, D-17487 Greifswald (Germany); (3) Formerly Forest Research, Alice Holt Lodge, Wrecclesham, GU10 4LH Farnham (UK); (4) Forest Services, Forestry Commission England, 620 Bristol Business Park, BS16 1EJ Bristol (UK)

@ TGM Sanders (tanja.sanders@ti.bund.de)

Received: Nov 20, 2012 - Accepted: Oct 17, 2013

Citation: Sanders TGM, Pitman R, Broadmeadow MSJ, 2014. Species-specific climate response of oaks (Quercus spp.) under identical environmental conditions. iForest 7: 61-69 [online 2013-11-18] URL: http://www.sisef.it/iforest/contents/?id=ifor0911-007

Communicated by: Marco Borghetti

comprises the highest percentage of broadleaved woodland in Great Britain but its yield is expected to decline in the south and east under future climate projections (Broadmeadow et al. 2005). These forests possess a high economic and socio-economic value (Evans 1984, Grant \& Edwards 2008), raising the question as to whether replacement with another oak species, better adapted to summer drought and wet winters, is an appropriate response to projected climate change. While Quercus species are believed to show high competitiveness under drier conditions than currently experienced in southern England (Abrams 1990, Broadmeadow et al. 2005, Eilmann et al. 2006), Thomas et al. (2002) found that a combination of waterlogging in winter and summer drought weakens oak to a level where diseases can attack more readily. Cases of drought-induced mortality have also been reported in Europe (Dreyer 1994, Brasier 1996, Gibbs \& Greig 1997, Allen et al. 2010). Modelled results presented by Attorre et al. (2008) suggest that the general assumption regarding drought sensitivity is invalid; instead, the performance of oak is dependent on origin and the characteristics of individual species. Other authors attribute the decline of oak in Europe to a combination of several factors, including infection by Phytophthora cinnamomi exacerbated by climatic factors (Brasier \& Scott 1994). Thomas \& Blank (1996) propose nutrient imbalance as the reason for oak decline, while Andersson et al. (2011) concluded that the decline of oak and its inevitable death is a long process which can begin decades previously.

Tree ring analysis can be used to better understand the potential for an onset of decline driven by responses to climate (Schweingruber 1988, 1990). Despite age and management-related variation in growth, the sensitivity of a species on a given site to environmental changes can be assessed (Friedrichs et al. 2009). Tree-ring analysis is regularly used to evaluate climate-growth interactions as well as establishing the drivers for tree mortality (Cook et al. 1987). While site conditions modulate climate-growth correlations (Wilson et al. 2008, Mérian et al. 2011) information on species-specific climate responses still can be derived (Carrer 2011, Sanders et al. 2012). This approach was the subject of a number of dendrochronological studies (Leblanc \& Foster 1992, Dwyer et al. 1995, Eilmann et al. 2006, Danek et al. 2007, Friedrichs et al. 2009, Helama et al. 2009, Di Filippo et al. 2010, Scharnweber et al. 2011). However, a direct comparison of the response to climate of different oak species growing in close proximity has not been undertaken for mature forest stands.

Our aims were: (1) to quantify growth dif- 


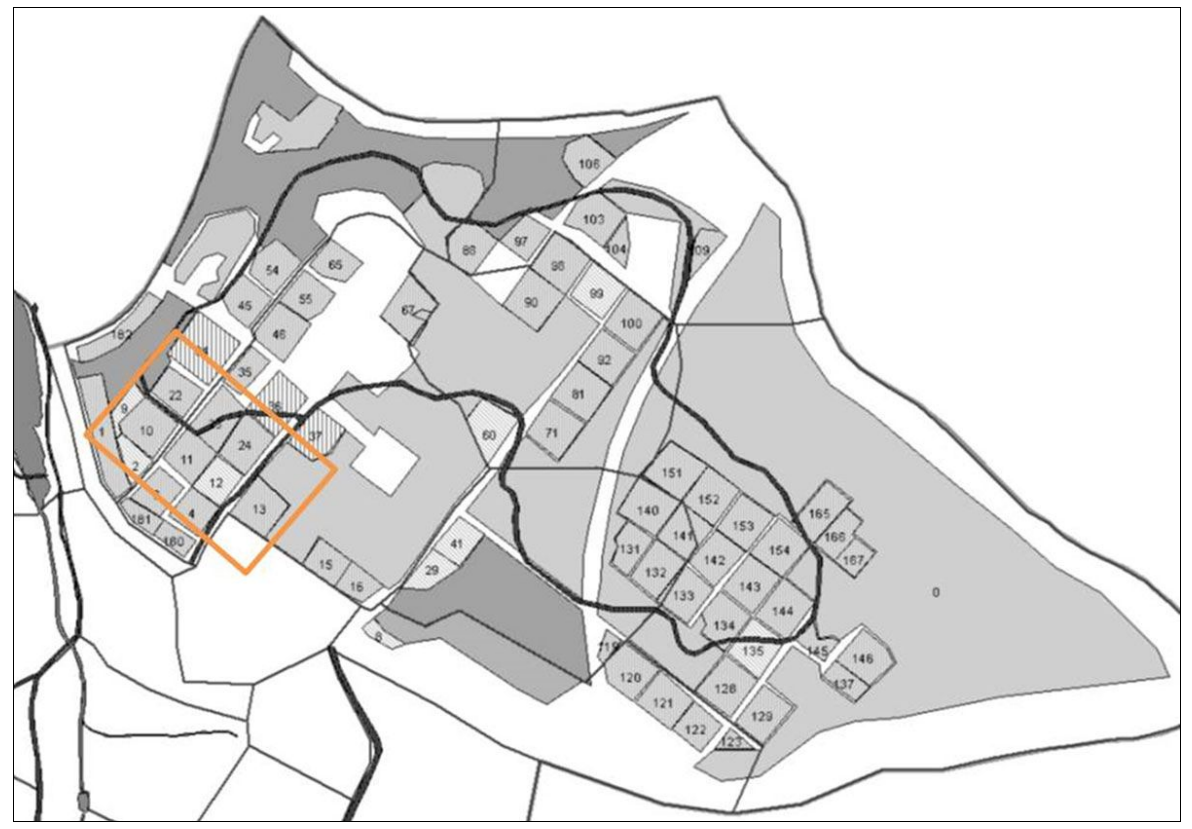

Fig. 1 - The species trial in Bedgebury, Kent (51 $04^{\prime} \mathrm{N}$ and $0^{\circ} 27^{\prime}$ East). The oak plots evaluated in this study are all in the north-west corner (orange square) of the plantation and measure $100 \mathrm{~m}^{2}$ each. Number codes are: Q. coccinea (10), Q. petraea (11), Q. robur (13), Q. palustris (23), and Q. frainetto (24). Source: Forestry Commission 2013.

ferences between five Quercus species from one plantation in Bedgebury, UK; and (2) to calculate climate-growth correlations based on daily data.

\section{Materials and Methods}

\section{Location and soil description}

The samples were taken at a species trial in Bedgebury, Kent in the southeast of Britain. Originating from research plots set up by Ovington (1953) in the late 1930's the trial is laid out in plots of a quarter of a hectare each (Fig. 1).

Planting and replanting of different species has occurred over the years and only a handfull of the original Ovington plots still exist. Heavy losses occurred in the $2^{\text {nd }}$ world war resulting in the need to re-establish the oak plots. The Bedgebury plantation has seen

heavy damage due to wind throw in the more recent past $(1987,1991)$; the oak stands, however, have been sheltered from wind damage due to their location in the northwestern area at the lowest point of the slope (Howard \& Howard 1984). Soils under the oak stands are acidic, permeable loams. Drainage is limited and waterlogging can occur, especially in winter and after heavy rainfall (Howard \& Howard 1984). The soils are phosphorus-deficient and generally low in other nutrients (Mitchell \& Westall 1972). Soil $\mathrm{pH}$ ranges from 5 to less than 4 (Ovington 1953, 1956, Ovington \& Madgwick 1958).

\section{Species selection}

The Quercus stands sampled in this study are in close proximity to one another within a $100 \times 200 \mathrm{~m}$ rectangle. The stands have

Tab. 1 - General information on the five investigated Quercus species.

\begin{tabular}{|c|c|c|c|}
\hline Species & $\begin{array}{l}\text { Common } \\
\text { name }\end{array}$ & Natural distribution & Site requirements \\
\hline Q. coccinea & Scarlet oak & $\begin{array}{l}\text { native to eastern and } \\
\text { central North America }\end{array}$ & $\begin{array}{l}\text { acidic, poor, sandy soils on dry } \\
\text { sides (Minckler 1965) }\end{array}$ \\
\hline Q. petraea & Sessile oak & native to Europe & $\begin{array}{l}\text { prefers clay or sandy soils with } \\
\text { humus }\end{array}$ \\
\hline Q. robur & English oak & $\begin{array}{l}\text { native to Europe, } \\
\text { northern and western } \\
\text { Africa }\end{array}$ & $\begin{array}{l}\text { moist and fertile well-drained soil } \\
\text { preferred, soil pH is not critical, } \\
\text { clay soils }\end{array}$ \\
\hline Q. palustris & Pin oak & $\begin{array}{l}\text { native to north-eastern } \\
\text { and north-central North } \\
\text { America }\end{array}$ & $\begin{array}{l}\text { moist, fertile acidic, well-drained } \\
\text { soils (Minckler 1965) }\end{array}$ \\
\hline Q. frainetto & Hungarian oak & $\begin{array}{l}\text { native to south-eastern } \\
\text { Europe }\end{array}$ & $\begin{array}{l}\text { Medium to heavy acidic soils, dry } \\
\text { and waterlogged tolerated }\end{array}$ \\
\hline
\end{tabular}

been thinned regularly and all have a closed canopy structure. The understory vegetation can be dense with some Rhododendron spp. present. Planted in the late 1950's they were about 45 years at time of sampling. Five different oak species were suitable for coring, namely $Q$. coccinea, $Q$. petraea, $Q$. robur, Q. palustris and Q. frainetto (Tab. 1).

\section{Climate data}

The location of the site in the southeast of Britain and its close proximity to the sea (between 15 to $30 \mathrm{~km}$ to the south and east respectively) results in a very stable climate. Mean temperature in winter (Dec-Feb) is typically around $4{ }^{\circ} \mathrm{C}$ with daily average minima around $-6{ }^{\circ} \mathrm{C}$ during the reference period (1960-1990). Monthly mean maximum temperature in summer (Jun-Aug) is approximately $27{ }^{\circ} \mathrm{C}$. Late ground frost can occur until June with measured grass temperatures below $0{ }^{\circ} \mathrm{C}$. Climate data was obtained at daily resolution from the Bedgebury Pinetum meteorological record which is taken within the plantation on a cleared area. The record starts on the $1^{\text {st }}$ January 1959 and runs over the complete period of investigation.

\section{Sampling and tree-ring width measurement}

Sampling took place in spring 2006. Two cores were taken (Suunto increment borers) from opposite directions on the trunk of five dominant trees, avoiding wounds and reaction wood for each species. Cores were prepared according to standard procedures given in Stokes \& Smiley (1968). Individual tree-ring width was measured using a LIN$\mathrm{TAB}$ measuring table and the software WinTSAP (both Rinntech, Heidelberg, Germany) at $1 / 1000 \mathrm{~mm}$ precision. Cross-dating and chronology building for all respective species was carried out using the same software. Cardinal splines (Fahrmeir \& Tutz 1994, pp. 156) were used for indexation (trend removal) of the individual and the species specific tree-ring series.

\section{Statistical analysis}

Expressed population signal (EPS) and mean inter-series correlation (Rbar) were calculated using the dendrochronological software library in R (Bunn 2008, R Core Team 2012). Autocorrelation (AR) was calculated using Durbin-Watson statistics, Kruskal-Wallis one-way analysis of variance on ranks and a pairwise multiple comparison procedure (Tukey Test) were performed for the complete, raw and indexed chronologies in SAS (SAS 9.3, SAS Institute Inc.). Annual sensitivity was calculated after Douglass (1928) as follows (eqn. 1):

$$
S_{a}=\left|\frac{2\left(x_{t+1}-x_{t}\right)}{\left(x_{t+1}+x_{t}\right)}\right|
$$


where $S_{\mathrm{a}}$ is the the annual sensitivity of one chronology, $x$ is the tree ring width, and $t$ is the year. Mean sensitivity is calculated as follows (eqn. 2):

$$
S_{\text {mean }}=\frac{1}{n-1} \sum_{t=1}^{t=n-1}\left|\frac{2\left(x_{t+1}-x_{t}\right)}{\left(x_{t+1}+x_{t}\right)}\right|
$$

where $S_{\text {mean }}$ is the mean sensitivity of one chronology and $n$ is the number of years of the chronology. A partitioning analysis was undertaken using annual mean, maximum and minimum temperature and precipitation sums as well as mean wind direction, mean cloud cover and mean sunshine hours (Jump, SAS Institute Inc.). Pointer years were identified for each species using the individually de-trended (exponential spline $\alpha=0.25$ ) chronologies, where increment of $75 \%$ of the sample trees deviated by more than one standard deviation from the mean (SAS 9.3, SAS Institute Inc.). Climate-growth correlations were calculated using the CLIMTREG software (Beck 2007, Beck \& Heussner 2011). This software uses daily climate variables to calculate climate-growth correlations. Remaining autocorrelation was removed from the indexed series by autoregressive modelling. A common interval analysis was used to detect climate-growth connections. Correlations were calculated using time spans from 21 to 121 days of climate data, starting on the $1^{\text {st }}$ July of the previous year to $31^{\text {st }}$ October of the current year. The deviations of mean temperature and precipitation sums were calculated from the longterm average, correlating the resulting climatic values with the tree-ring index time series (Beck et al. 2013). To verify the results of CLIMTREG, a Pearson's Product Moment Correlation was used. While not as detailed and based on monthly averaged data, it confirmed the general trends between species and climate on this site.

\section{Results}

\section{Environmental conditions}

Whilst the soils are typical for lowland area of SE England, they are not optimal for all Quercus species planted. While $Q$. frainetto prefers these heavy, acidic soils and can tolerate water-logging, $Q$. palustris and $Q$. robur would benefit from more fertile soils with better drainage. $Q$. petraea and especially $Q$. coccinea are better suited to lighter, sandy soils.

Minimum air temperatures (Fig. 2a) were higher in the period from 1991 to 2005 than in the reference period (1960 to 1990). A general increase in minimum air temperatures is evident over the course of the temperature record which becomes significant $(\mathrm{p}<0.10)$ in spring. Grass temperatures (Fig. $2 b)$ decrease $(p<0.10)$ in all but the summer months where a slight increase is observed

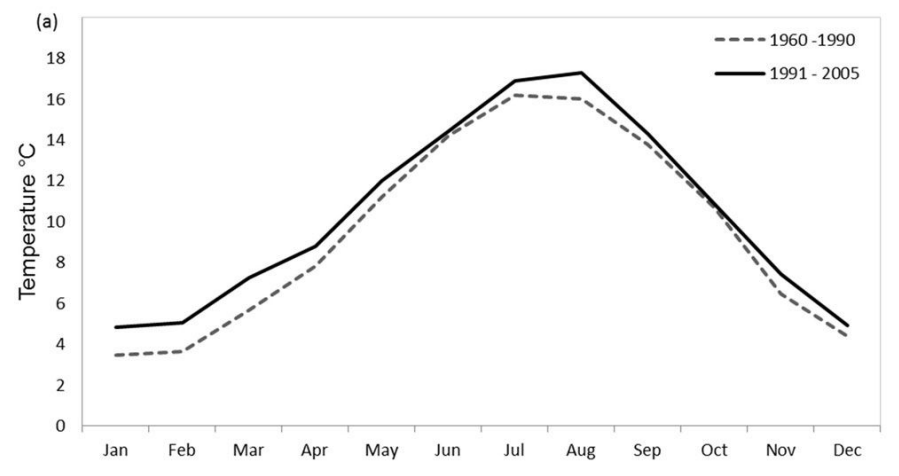

Fig. 2 - Mean temperature (a), grass temperature (b), and precipitation sums (c) for the periods 1960 to 1990 and 1991 to 2005 at the Bedgebury Pinetum.
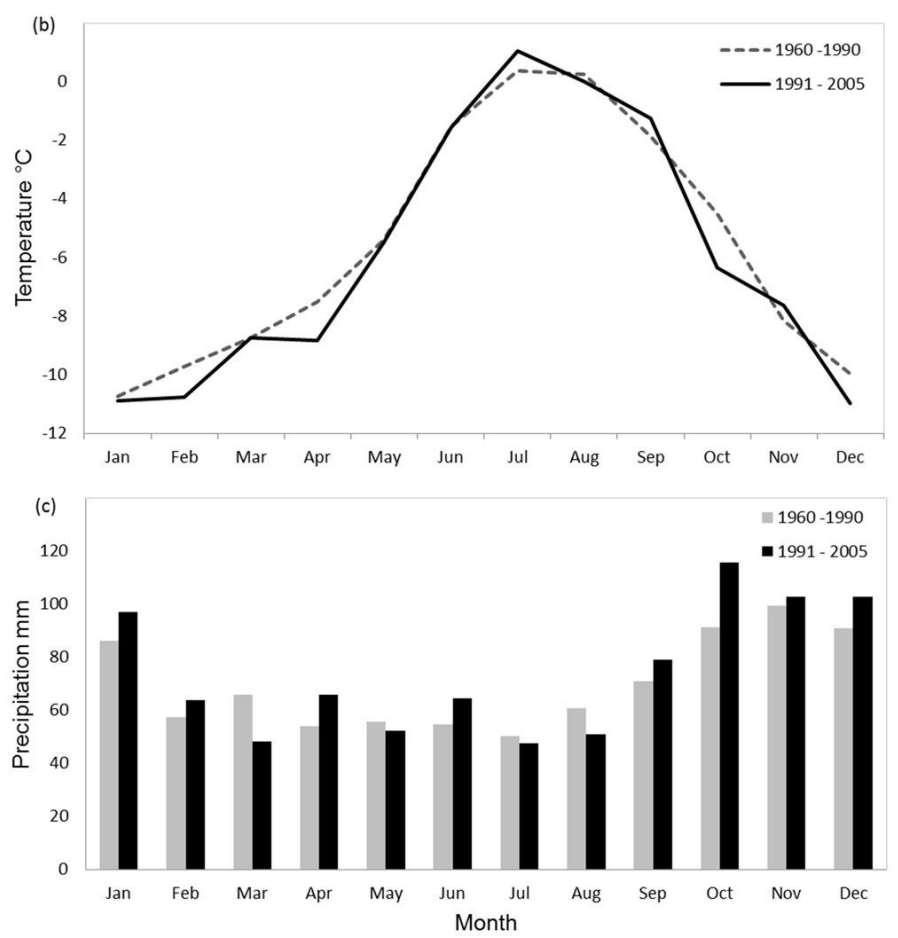

(not significant). The largest reduction is evident in May and June $(p<0.001)$. A decline in precipitation (Fig. 2c) over the period was significant for January, February and March $(\mathrm{p}<0.05)$. A slight increase was found in June, September and October. Year-to-year variation is high for all but grass temperature.

A difference in grass temperature is evident between the two periods (1961-90 and 19912005 - Fig. 2b) characterised by colder spring temperatures and warmer autumns in

the latter period. Precipitation shows a homogeneous distribution over the years with heavy rainfall occurring in the winters of 1968, 1986, 1998 and 2003. Heavy rainfall in spring was recorded in 2002.

\section{Tree-ring series}

The mean segment length is 45 years and average growth rates vary between $2.37 \mathrm{~mm}$ and $2.94 \mathrm{~mm}$ per year with standard deviations between $0.68 \mathrm{~mm}$ and $0.38 \mathrm{~mm}$ (Tab. 2).

Tab. 2 - Statistics of tree ring data and chronologies. (MSL): mean segment length; (AGR): average growth rate (mm); (EPS): expressed population signal; (AR): auto correlation (1), Durbin Watson (2); (SNR): signal-to-noise ratio; (MSS): mean signal strength.

\begin{tabular}{lcccccccccc}
\hline & & \multicolumn{4}{c}{ Raw data / single trees } & \multicolumn{3}{c}{ Residual chronology } \\
\cline { 5 - 11 } Species & $\begin{array}{c}\text { T } \\
\text { no }\end{array}$ & $\begin{array}{c}\text { S } \\
\text { no }\end{array}$ & MSL & AGR & $\begin{array}{c}\text { Std. } \\
\text { dev. }\end{array}$ & $\begin{array}{c}\text { AR } \\
\text { (1) }\end{array}$ & $\begin{array}{c}\text { AR } \\
\text { (2) }\end{array}$ & $\begin{array}{c}\text { Mean } \\
\text { sens }\end{array}$ & EPS & SNR \\
\hline Q. coccinea & 5 & 10 & 45 & 2.94 & 0.47 & $0.45^{*}$ & 0.25 & 0.15 & 0.87 & 6.41 \\
Q. petraea & 5 & 10 & 45 & 2.35 & 0.38 & $0.39^{*}$ & 0 & 0.12 & 0.84 & 5.4 \\
Q. robur & 5 & 10 & 45 & 2.37 & 0.43 & $0.55^{*}$ & $0.39^{*}$ & 0.19 & 0.8 & 4.1 \\
Q. palustris & 5 & 10 & 45 & 2.88 & 0.45 & $0.69^{*}$ & $0.5^{*}$ & 0.12 & 0.79 & 2.44 \\
Q. frainetto & 5 & 10 & 45 & 2.83 & 0.68 & $0.62^{*}$ & $0.5^{*}$ & 0.15 & 0.81 & 4.27 \\
\hline
\end{tabular}


Fig. 3 - Comparison of raw annual growth series over the common period of 45-years (a) and the cumulative growth values of the five oak species (b).
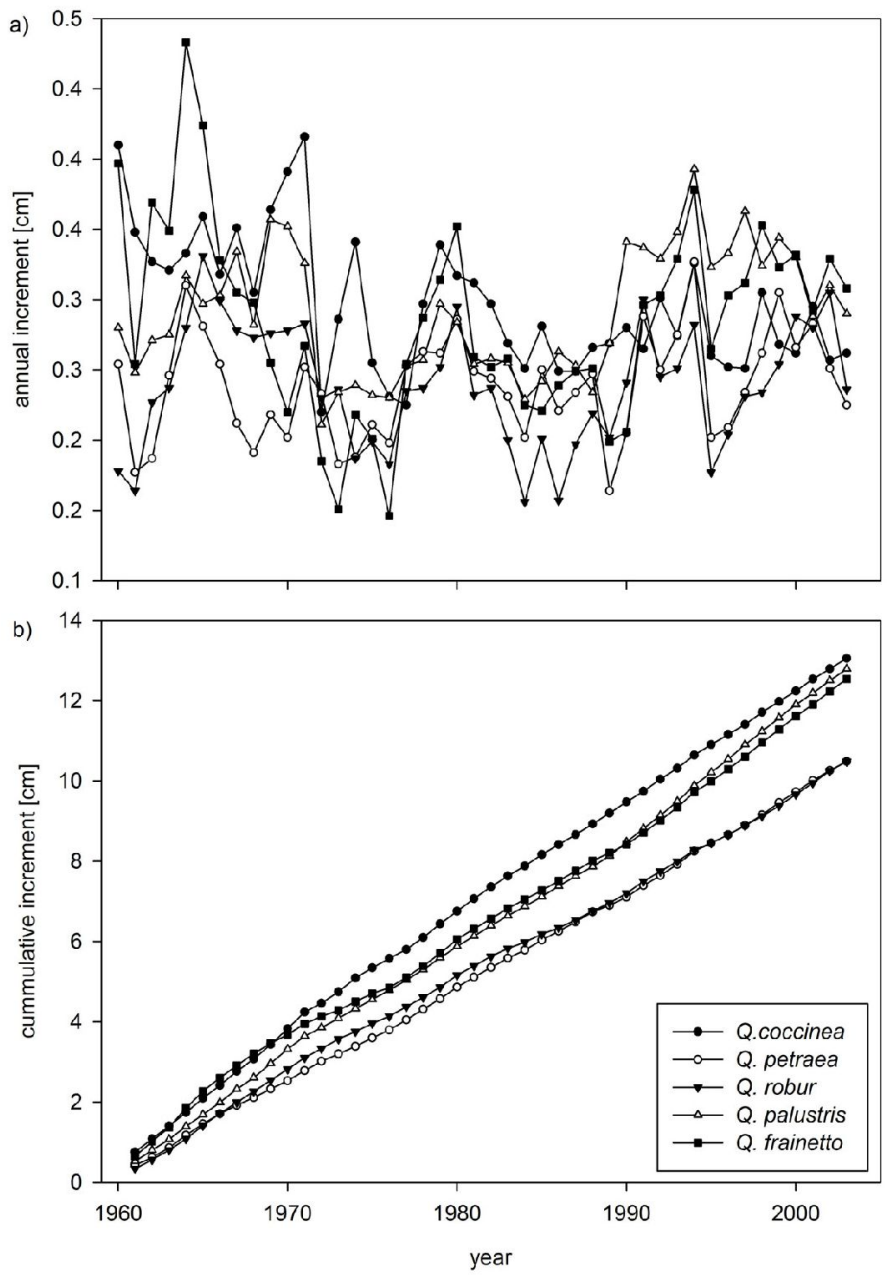

Mean signal strength (MSS) is a measure of uniformity between sampled trees of their annual growth response. MSS varies between 0.32 for $Q$. frainetto and 0.55 for $Q$. palustris. The signal-to-noise-ratio (SNR) quantifies the strength of the common signal for all trees in a chronology (Wigley et al. 1984) and falls between 2.4 and $6.4 \%$. The Expressed Population Signal (EPS) for the residual chronology varies between 0.79 and 0.86 . EPS provides an estimate of the ex-

plained variance of the sample chronology for the site. Autocorrelation (AR) is a measure of the dependency of annual growth rate on the growth rate observed in the previous years. All species show significant autocorrelation, with the previous year, with the previous two years in the case of $Q$. robur and $Q$. palustris (Tab. 2), while $Q$. frainetto and Q.palustris show a significant autocorrelation with the previous three years (not shown).

Fig. 4 - Box-whisker plots of mean growth over the common growth period with variability data for individual cores shown (black dots)

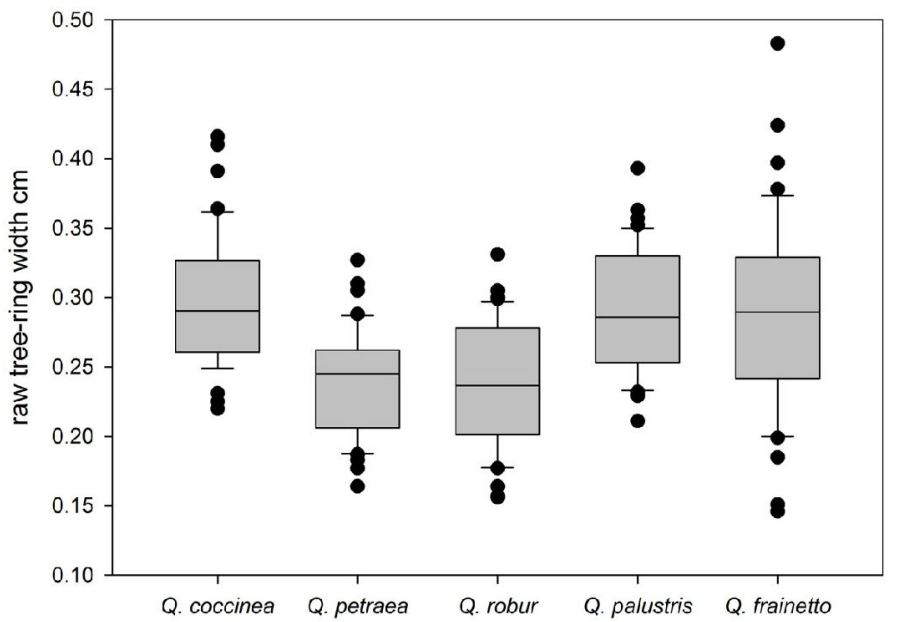

Annual growth variations and sensitivity

The annual increment patterns (Fig. 3a) show similar long-term trends for all five species, with reduced growth evident in the mid-1970s, mid-1980s, mid-1990s and towards the end of the chronologies in 2005. This is consistent with well-documented summer drought conditions in Britain in 1976, 1984, 1995 and 2003 (Innes 1990, Morecroft et al. 2002, Hendry et al. 2005). Negative pointer years (i.e., radial growth is less than one standard deviation from the mean for $75 \%$ of sample trees) for $Q$. coccinea occurred in 1956, 1968, 1972 (strongest negative pointer year), 1975-76, 1986, 1995, and 1999; positive pointer years were identified for 1958 (strongest positive pointer year), 1959, 1967, 1969, 1974, 1978, 1994, and 1998. Negative pointer years are evident for Q. petraea in 1989 and 1995. None of the other species show significant pointer years in the period covered by the meteorological data. However, the common reaction to the drought years of 1976 and 1995 is apparent. Recovery is quickest for $Q$. palustris, $Q$. frainetto, and $Q$. robur, while $Q$. petraea shows the longest growth depression following the drought years. $\mathrm{Cu}$ mulative diameter increment, used here as an indication of timber volume (Fig. 3b), shows that $Q$. frainetto experienced suppressed growth in the early 1940s at about 10 years of age, after having the highest juvenile growth rate of the five species.

$Q$. coccinea demonstrates the most consistent growth rate with only a minimal setback at about 20 years of age. The growth rate of $Q$. frainetto is less than that of at the beginning of the chronology. However, no period of suppressed growth is evident for $Q$. coccinea and its cumulative radial growth exceeds that of $Q$. frainetto at the time of sampling. The growth of $Q$. palustris is below the two previous species at until about 30 years of age when it excels $Q$. frainetto. The two species native to the UK, Q. robur and $Q$. petraea, show lower growth rates at the beginning of the chronology, but attain the same cumulative diameter growth by time of sampling. A small difference is apparent between eight and 28 years of age when the radial growth of $Q$. robur was greater greater than that of $Q$. petraea. Subsequently the growth rate of $Q$. robur declined compared to $Q$. petraea.

The Kruskal-Wallis one-way analysis of variance on ranks showed a significant $(p<0.001)$ difference in the mean values between the species. To isolate the groups differing the most, multiple comparison was used showing significant differences $(p<0.05)$ between the group of the American and southern European species (Q. coccinea, $Q$. palustris and $Q$. frainetto) and the two species native to the UK (and widely across 
Europe) Q. petraea and Q. robur.

The mean growth over the common period of study shows, however, not only the highest mean growth rates for $Q$. coccinea but also the high variability for $Q$. frainetto with $Q$. coccinea in second place. The two species native to the UK show the least variability in growth rate combined with the smallest mean growth over the period of study (Fig. 4).

Mean sensitivity for all species lies between 0.12 and 0.19 . The greatest sensitivity to environmental conditions is evident for $Q$. coccinea, $Q$. frainetto and $Q$. palustris $(0.41$ to 0.62$)$ at the end of the 1950 's and 1970 's. $Q$. robur has the lowest sensitivity reaching minimum values below 0.1 in the 1960's.

\section{Climate-growth reactions}

Partitioning of climate-growth reactions

Tab. 3 - Results of the partitioning analysis for main climate variables of the vegetation period showing threshold values of reaction and the expected change in tree-ring width when exceeding or undercutting the values.

\begin{tabular}{lccccccc}
\hline \multirow{2}{*}{ Species } & \multicolumn{2}{c}{ Thresholds for positive responses } & \multicolumn{3}{c}{ Thresholds for negative responses } \\
\cline { 2 - 7 } & $\begin{array}{c}\text { P sum } \\
(\mathbf{m m})\end{array}$ & $\begin{array}{c}\max \mathbf{T} \text { sum } \\
\left({ }^{\circ} \mathbf{C}\right)\end{array}$ & $\begin{array}{c}\min \mathbf{T} \text { sum } \\
\left({ }^{\circ} \mathbf{C}\right)\end{array}$ & $\begin{array}{c}\text { P sum } \\
(\mathbf{m m})\end{array}$ & $\begin{array}{c}\max \text { T sum } \\
\left({ }^{\circ} \mathbf{C}\right)\end{array}$ & $\begin{array}{c}\min \text { T sum } \\
\left({ }^{\circ} \mathbf{C}\right)\end{array}$ \\
\hline Q. coccinea & - & - & - & - & - & $<1592 \downarrow$ \\
Q. petraea & $>250 \uparrow$ & $<2874 \uparrow$ & $>1592 \uparrow$ & $<250 \downarrow$ & $>2874 \downarrow$ & - \\
Q. robur & - & - & - & $<247 \downarrow$ & $>2846 \downarrow$ & - \\
Q. palustris & $>314 \uparrow$ & $>2926 \uparrow$ & - & $<314 \downarrow$ & - & - \\
Q. frainetto & $>242 \uparrow$ & - & - & $<242 \downarrow$ & $>2906 \downarrow$ & - \\
\hline
\end{tabular}

(Tab. 3) shows a clear separation between the three European oak species ( $Q$. petraea, $Q$. robur, $Q$. frainetto) and the two North American species ( $Q$. coccinea, $Q$. palustris).

$Q$. frainetto, $Q$. robur and $Q$. petraea all show a decline in growth below a precipita- tion sum for May to September of less than than 242,247 and 250, respectively, while the strongest response of $Q$. coccinea is to minimum temperatures. Q. palustris shows a positive response to maximum temperatures with tree-ring growth further enhanced when May to September precipitation is above 314 (a)

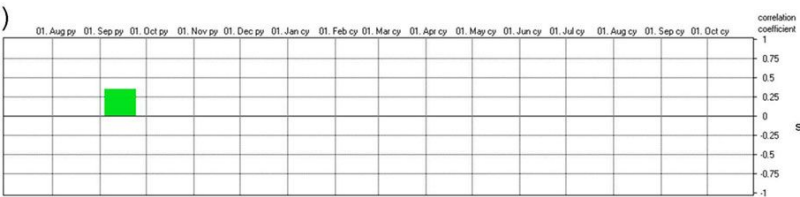

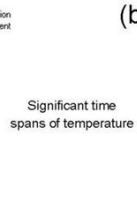

(b)

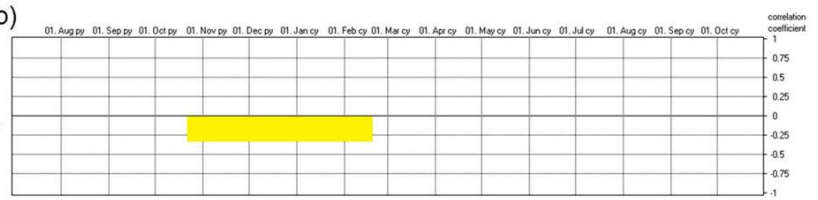

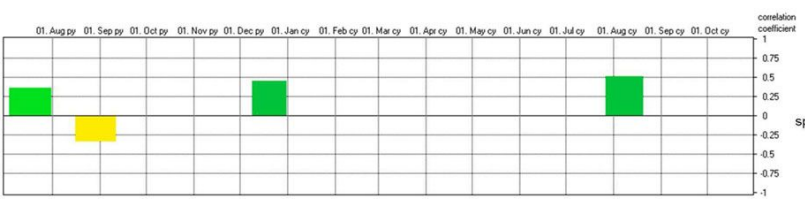
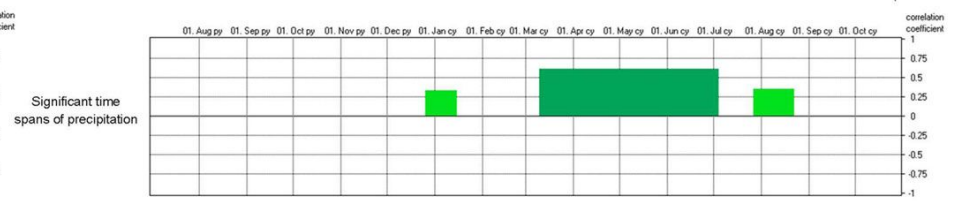

(c)

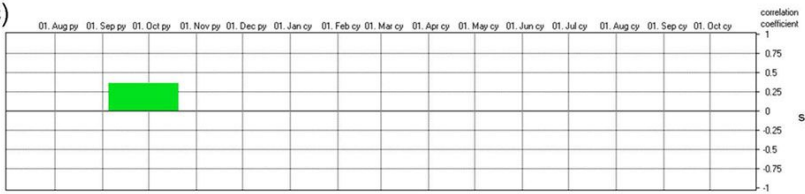

(d
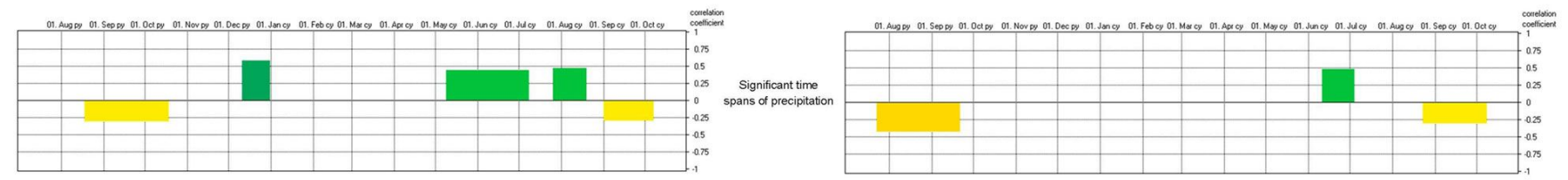

(e)
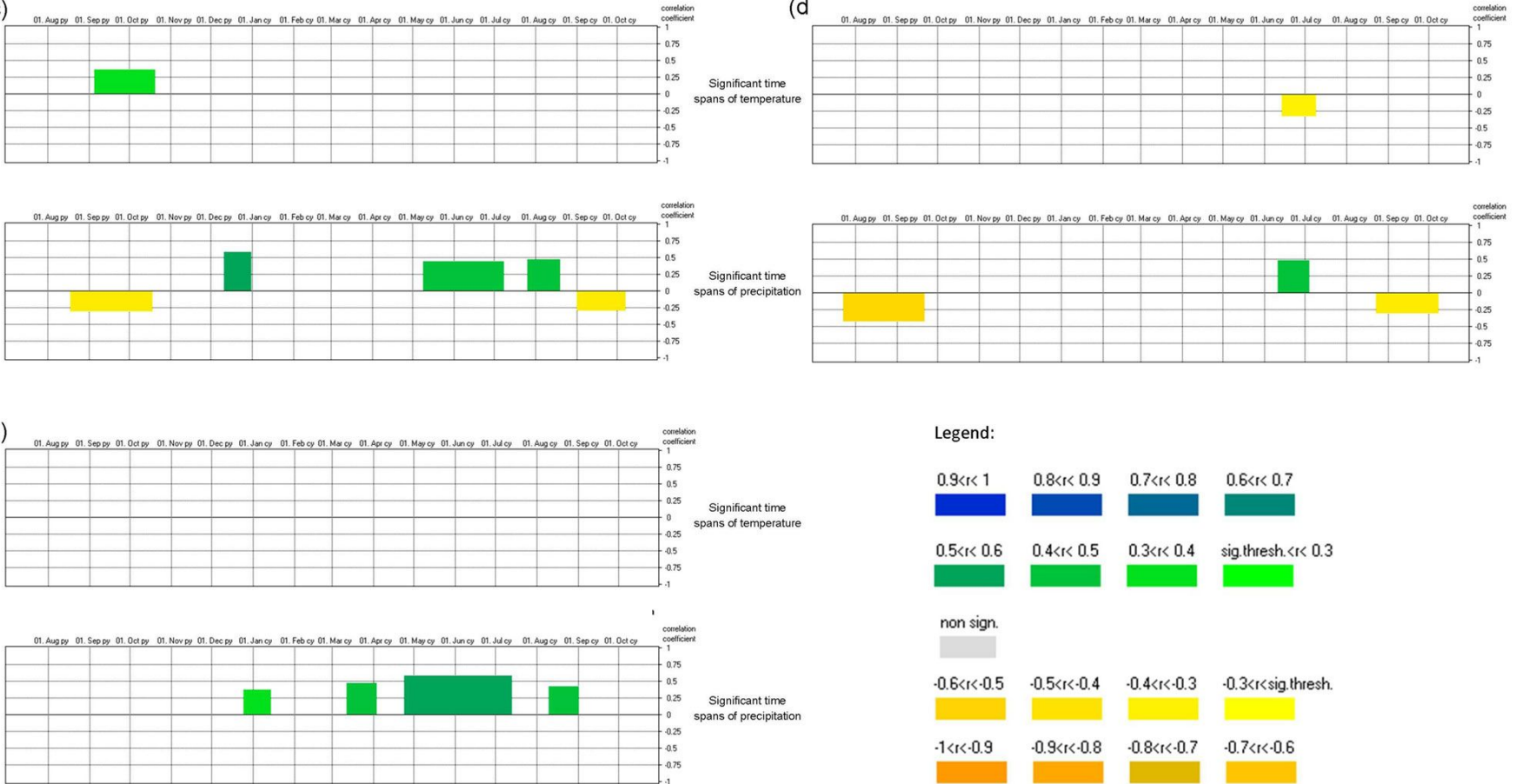

Fig. 5 - Climate-growth correlation between temperature (top) and precipitation (bottom) for Q. coccinea (a), Q. petraea (b), Q. palustris (c), Q. robur (d), and Q. frainetto (e). Significance levels range from +1 (dark blue) to -1 (red) and are additionally provided on the right y-axis for each individual diagram. The width of the columns provides information on the length of persistence of each correlation with the dates given on the top $\mathrm{x}$-axis of each diagram, beginning with the $1^{\text {st }}$ June of the previous year and ending with the $31^{\text {st }}$ October of the current year. 


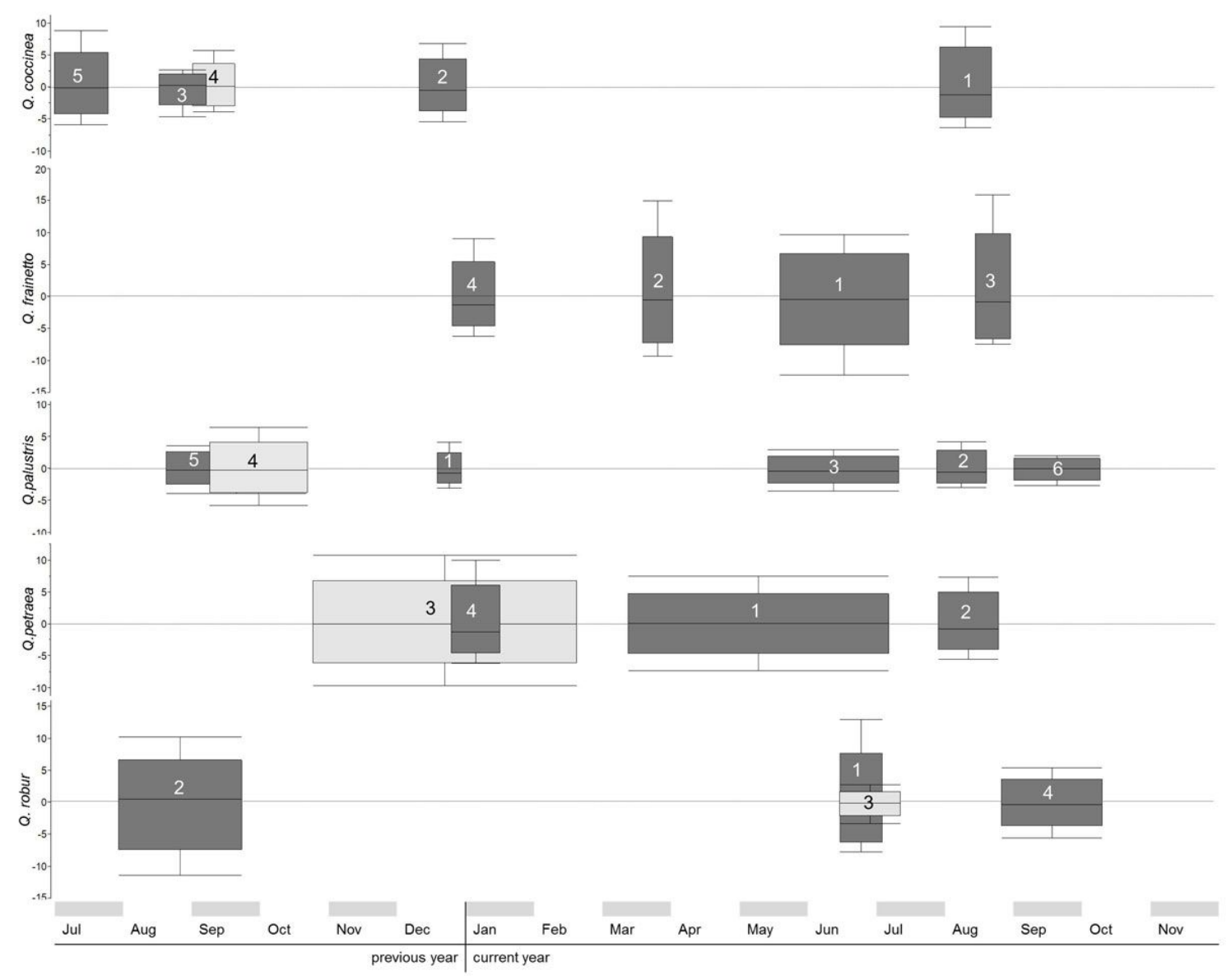

Fig. 6 - Explained variation in tree-ring width to precipitation (dark grey) and temperature (light grey) of $Q$. coccinea, $Q$. petraea, Q. palustris, $Q$. robur, and $Q$. frainetto from July previous year to November current year; scale indicating $10 \%$ variance for the top three species and 15 and $20 \%$ for the bottom two, respectively.

$\mathrm{mm}$; however, the decline in growth below the precipitation threshold is not statistically significant.

The climate-growth correlations using daily data (Fig. 5a-e) show the different responses to climate for the five species grown under the same environmental conditions.

$Q$. coccinea responds positively to temperature during the the previous autumn. Positive correlations with precipitation are apparent for the previous year's summer and winter periods, and with summer in the current year. Small negative correlations with precipitation are found from mid-August to mid-September of the previous year. $Q$. petraea responds negatively to temperature from mid-October all the way through to mid-February (i.e., growth in the current year is higher when conditions were cold in the previous early autumn). Correlations with precipitation are positive and evident at the beginning of January, from the beginning of March to early July and, again, between the end of July to mid-August. Q. palustris displays a positive correlation to temperature in the previous year's autumn. Positive correlations to precipitation are strongest in December of the previous year. Also significant are positive responses to precipitation from May to July and, again, in August of the current year. Negative reactions to precipitation are found, albeit weaker, in the au- tumn of both the previous and current years. The correlation to temperature of $Q$. robur is weakly negative from mid-June to the second week of July. During the same period, a positive correlation with precipitation is apparent. Negative correlations with precipitation are evident in the late summer of both the current and previous years. No significant correlations with temperature are found for $Q$. frainetto but positive correlations with precipitation occur in mid-winter, mid-March, from the end of April until midJuly and at the end of August.

Using these climate-growth correlations for each species we calculated the explained variance in growth (Fig. 6). For each significant climate-growth correlation, the maximum, mean and minimum tree-ring width is used to produce individual box-plots. The width of the box plots corresponds to the period (in days) of the significant correlations for each species. The mean of the boxplots gives the likely variance in tree-ring width (indexed) caused by a change in climate in the respective periods. The height of the boxes indicates the $25^{\text {th }}$ and $75^{\text {th }}$ percentile respectively as well as absolute maxima and minima (whiskers). Presenting the results in this way allows a comparison to be made between the five species of the strength of the response to these two climate drivers of tree growth. $Q$. robur and $Q$. frainetto show the strongest variation in radial increment to temperature and precipitation. Tree-ring width of the other species varies less.

The response of $Q$. petraea and $Q$. frainetto are notably to the current year's conditions, in contrast to the other species where precipitation of the previous year are important ( $Q$. robur and $Q$. coccinea), and temperature for $Q$. palustris.

\section{Discussion}

Studies on climatic influences on the growth of $Q$. robur and Q. petraea are extensive (e.g., Anderson \& Adams 1978, Friedrichs et al. 2009, Arend et al. 2011, Mérian et al. 2011, Mérian \& Lebourgeois 2011). The same is true for several controlled experiments (Broadmeadow \& Jackson 2000, Hu et al. 2013, Kuster et al. 2013). The situation is similar for $Q$. coccinea (Abrams 1990, 1996, Jenkins \& Pallardy 1995, Speer et al. 2009) but less so for $Q$. palustris (Robertson 1992, Leavitt 2002) in America. For $Q$. frainetto there is a lack of research (Chatziphilippidis \& Spyroglou 2004) particularly for climate-growth analysis using tree-rings. Griggs et al. (2007) reported that $Q$. petraea, $Q$. robur and $Q$. frainetto share a common climate signal at their southern distribution but were unable to distinguish the species due to the historic 
source of the timber. These findings could not be confirmed in this study, neither for $Q$. petraea, Q. robur, nor for $Q$. frainetto at this western edge of its distribution. The sensitivity to the two climate variables investigated in this study was low for all five species, indicating that none of them were close to the edge of their climatic envelope. The low year-to-year variability and the significantly high AR is a sign of stable growth conditions (Beck \& Heussner 2011).

Increment is highest for $Q$. coccinea, a species known for its rapid growth (Minckler 1965) on a variety of soil types in a wide range of climates. However, it is generally found in regions with a relatively moist climate characterised by more than $760 \mathrm{~mm}$ annual precipitation; despite this, observations suggest that it is better suited to dry, welldrained soils. In this study its high average increment is accompanied by high inter-annual variability and the highest number of pointer years. $Q$. coccinea shows a strong negative reaction to summer drought but it also demonstrates the strongest positive response to temperature. This might give the species a competitive advantage under warming conditions in years not characterised by summer drought. $Q$. palustris on the other hand is, as its common name "Spanish swamp oak" implies, tolerant of moist soi conditions and grows primarily on poorly drained and seasonally (winter) flooded sites. In this study a positive response to summer precipitation was evident, but with low inter-annual variability in increment However, exposure to declining summer precipitation might change this as the climate changes. Both native oak species would be likely to decline in response to climate projections of rising temperatures and declining summer precipitation; however $Q$. robur seems to be more able to tolerate an increase in summer temperatures and is slightly less affected by summer drought than Q. petraea on the basis of responses to climate variables over the chronology covered by this study The results also suggest that $Q$. frainetto is likely to experience the severest decline under climate change projections of hotter drier summers. This is consistent with observations from Greece where its distribution is limited by summer drought and soil nutrient availability (Spyroglou \& Chatziphilippidis 2007). The relative response of the five species to climate variables outlined in the partitioning analysis (Tab. 3) is consistent the results from the climate-growth analysis While the drought-tolerant species $Q$. coccinea only shows a growth decline when temperatures in the "vegetation period" are below the threshold sum of $1592^{\circ} \mathrm{C}$, none of the other species show a negative reaction to low temperatures.

The Expressed Population Signal (EPS) is a measure of the strength of the common sig- nal within a chronology, where the threshold is set at 0.85 (Wigley et al. 1984); however, this threshold value is not universally applied (Wigley et al. 1984, Franklin 2013). Where there is a strong common signal within a chronology (i.e., high EPS value), this is generally driven by climatic factors pointer years clearly evident. The chronologies for all five species presented in this study show consistent annual growth and high autocorrelation (AR), indicating relatively limited climatic influences on growth rates. While the low EPS values could result from the low sample size, they could also be explained by the low sensitivity to climate and the high AR. This argument is strengthened by the low SNR-values, providing further evidence of the limited effects of climate on the growth of $Q$. robur, $Q$. palustris and $Q$. frainetto during the period of the chronologies (Oberhuber et al. 1998) on the sites for the species. Rozas (2005) found similar low values for SNR and EPS for young $Q$. robur growing in Spain, while Pilcher \& Baillie (1980) report low SNR values for a modern oak chronology in Ireland. In Germany EPS-values of less than 0.84 were reported for $Q$. petraea and $Q$. robur by Friedrichs et al. 2009. Even lower values have been reported for some other species, including Fagus sylvatica $(0.818$ - Tardif et al. $2001)$ and Nothofagus (0.77 - Cullen et al. 2001). The variability reported here is higher than that reported by Rozas (2005), possibly due to the younger age of the oak trees sampled.

$Q$. petraea the slowest growing species over the course of the study was highly sensitive to climatic variables and exhibited the longest period of reduced growth following pointer years. $Q$. robur represents a more suitable species to plant in the UK as an adaptation measure given projections of hotter, drier summers and its ability to make a more rapid recovery following negative pointer years.

\section{Conclusion}

Analysis of growth variability of five species of oak at a southern British site has enabled a comparison of their response to climatic variation over nearly 50 years. This has provided new information on the extent of their reaction and speed of recovery to extreme climatic events, and highlighted that the growth of some species is dependent on antecedent conditions in previous years. The analysis has provided some of the vital background needed to inform current forestry policy, which is establishing appropriate adaptation measures to respond to the threats of climate change (see Ray et al. 2010).

$Q$. petraea was the slowest growing species over the course of the study, and appeared to be highly sensitive to climatic variables exhibited the longest period of reduced growth following pointer years. Q. robur therefore represents a more suitable species to plant in the UK as an adaptation measure given projections of hotter, drier summers and its more rapid recovery in growth rate following extreme climatic events. The results indicate that the planting of some species of oak, not native to the UK, offers potential as an adaptation measure, either to diversify species choice or to replace native species of oak on very dry sites. Of the three non-native species evaluated in this study, Q. palustris showed the smallest response to changes in climate variables and may therefore have some potential as an alternative species. However, the partitioning analysis indicated that reduced growth rates occurred at a lower precipitation sum than for the two native species, which may be more significant if summer droughts were more intense than those experienced during the course of this study. In terms of overall growth rates $Q$. coccinea is superior to the other four species investigated in this study, with no negative impacts of drought apparent. It could therefore be a suitable choice as an adaptation measure in dry areas with poor nutrient supply, particularly on sandy soils. The sensitivity of $Q$. frainetto to summer drought suggests that the species is unlikely to represent an appropriate alternative to native species of oak.

Apart from the evaluation of future climatic suitability presented in this study, a much wider range of factors, including timber quality, needs to be taken into account when considering whether to select alternative, non-native species as a climate change adaptation measure when planting new woodland. Non-native species of oak, particularly those from outside Europe may not support the same biodiversity as native species of oak, while they may also be susceptible to pests and diseases that are endemic to the UK, but not present in their native range. There are also a number of landscape and cultural issues to consider, as the form and appearance of both $Q$. palustris and $Q$. coccinea is very different to that of the two native species.

\section{Acknowledgements}

Two anonymous reviewers greatly improved an early version of this manuscript with their input. We are grateful to the team of the Forestry Commission at Bedgebury Pinetum and James Pitman for their support on site.

\section{References}

Abrams MD (1990). Adaptations and responses to drought in Quercus species of North America. Tree Physiology 7: 227-238. - doi: 10.1093/ treephys/7.1-2-3-4.227

Abrams M (1996). Distribution, historical development and ecophysiological attributes of oak 
species in the eastern United States. Annales des Sciences Forestières 53 (2-3): 487-512. - doi: 10.1051/forest: 19960230

Allen CD, Macalady AK, Chenchouni H, Bachelet $\mathrm{D}$, McDowell N, Vennetier M, Kitzberger $\mathrm{T}$, Rigling A, Breshears DD, Hogg EH, Gonzalez P, Fensham R, Zhang Z, Castro J, Demidova N, JLim H, Allard G, Running SW, Semerci A, Cobb $\mathrm{N}$ (2010). A global overview of drought and heat-induced tree mortality reveals emerging climate change risks for forests. Forest Ecology and Management 259: 660-684. - doi: 10.1016/j.foreco.2009.09.001

Anderson RC, Adams D (1978). Species replacement patterns in central Illinois white oak forests. In: "Central Hardwood Forest Conference II". Department of Forestry and Natural Resources, Purdue University, West Lafayette, IN, USA, pp. 284-301

Andersson M, Milberg P, Bergman K-O (2011). Low pre-death growth rates of oak (Quercus robur L.). Is oak death a long-term process induced by dry years? Annals of Forest Science 68: 159-168. - doi: 10.1007/s13595-011-0017-y

Arend M, Kuster T, Günthardt-Goerg MS, Dobbertin M (2011). Provenance-specific growth responses to drought and air warming in three European oak species (Quercus robur, Q. petraea and $Q$. pubescens). Tree Physiology 31: 287-297. - doi: 10.1093/treephys/tpr004

Attorre F, Francesconi F, Scarnati L, De Sanctis M, Alfò M, Bruno F (2008). Predicting the effect of climate change on tree species abundance and distribution at a regional scale. iForest 1: 132139. - doi: 10.3832/ifor0467-0010132

Beck W (2007). Finding best regression approach for description of climate-growth relationships by floating time spans of varying width. In: Proceedings of the "DENDROSYMPOSIUM 2006". Tervuren (Belgium) 20-22 Apr 2006. Scientific Technical Report STR07/03, Potsdam, Germany. Beck W, Heussner K-U (2011). Tree sensitivity sign of senescense. In: Proceedings of the "DENDROSYMPOSIUM 2011" (Gärtner H, Rozenberg $\mathrm{P}$, Montès $\mathrm{P}$, Bertel $\mathrm{O}$, Heinrich $\mathrm{I}$, Helle G eds). Orléans (France) 11-14 May 2011. Scientific Technical Report STR11/03, Helmoltz Gemeinschaft, Potsdam, Germany.

Beck W, Sanders TG, Pofahl U (2013). CLIMTREG: Detecting temporal changes in climate-growth reactions - A computer program using intra-annual daily and yearly moving time intervals of variable width. Dendrochronologia 31 (3): 232-241. - doi: 10.1016/j.dendro.2013.02. 003

Bolte A, Ammer C, Löf M, Madsen P, Nabuurs GJ, Schall P, Spathelf P, Rock J (2009). Adaptive forest management in central Europe: climate change impacts, strategies and integrative concept. Scandinavian Journal of Forest Research 24: 473-482. - doi: 10.1080/028275809034182 24

Brasier C (1996). Phytophthora cinnamomi and oak decline in southern Europe. Environmental constraints including climate change. Annales des Sciences Forestières 53 (2-3): 347-358. - doi: 10.1051/forest: 19960217

Brasier CM, Scott JK (1994). European oak declines and global warming: a theoretical assessment with special reference to the activity of Phytophthora cinnamomi. EPPO Bulletin 24: 221-232. - doi: 10.1111/j.1365-2338.1994.tb010 63.x

Broadmeadow MSJ, Jackson SB (2000). Growth responses of Quercus petraea, Fraxinus excelsior and Pinus sylvestris to elevated carbon dioxide, ozone and water supply. New Phytologist 146: 437-451. - doi: 10.1046/j.1469-8137.2000. 00665.x

Broadmeadow MSJ, Ray D, Samuel CJA (2005). Climate change and the future for broadleaved tree species in Britain. Forestry 78: 145-161. doi: 10.1093/forestry/cpi014

Bunn AG (2008). A dendrochronology program library in R (dpIR). Elsevier, Jena, Germany.

Carrer M (2011). Individualistic and time-varying tree-ring growth to climate sensitivity. PLoS ONE 6 (7): e22813. - doi: 10.1371/journal.pone. 0022813

Chatziphilippidis G, Spyroglou G (2004). Sustainable management of coppice forests in Greece. In: "Towards the Sustainable Use of Europe's Forests - Forest Ecosystem and Landscape Research: Scientific Challenges and Opportunities" (Andersson F, Birot Y, Paivinen R eds). EFI Proceedings 49, Joensuu, Finland, pp. 51-60. [online] URL: http://www.efi.int/files/attachments/ publications/proc49_net.pdf

Cook ER, Johnson AH, Blasing TJ (1987). Forest decline: modeling the effect of climate in tree rings. Tree Physiology 3: 27-40. - doi: 10.1093/ treephys/3.1.27

Cullen LE, Palmer JG, Duncan RP, Stewart GH (2001). Climate change and tree-ring relationships of Nothofagus menziesii tree-line forests. Canadian Journal of Forest Research 31: 19811991

Danek M, Klusek M, Krapiec M (2007). The oak chronology (948-1314 AD) for the Zary area (SW Poland). Geochronometria 26: 47-52. - doi: 10.2478/v10003-007-0006-1

Di Filippo A, Alessandrini A, Biondi F, Blasi S, Portoghesi L, Piovesan G (2010). Climate change and oak growth decline: dendroecology and stand productivity of a Turkey oak (Quercus cerris L.) old stored coppice in central Italy. Annals of Forest Science 67: 706-706. - doi: $10.1051 /$ forest/2010031

Douglass AE (1928). Climatic cycles and tree growth: a study of the annual rings of trees in relation to climate and solar activity, Carnegie Inst., Washington Publ., Washington, DC, USA. Dreyer E (1994). Water stress, xylem dysfunctions and dieback mechanisms in European oak trees. INRA Nancy, Champenoux, France.

Dwyer JP, Cutter BE, Wetteroff JJ (1995). A dendrochronological study of black and scarlet oak decline in the Missouri Ozarks. Forest Ecology and Management 75: 69-75. - doi: 10.1016/ 0378-1127(95)03537-K

Eilmann B, Weber P, Rigling A, Eckstein D (2006). Growth reactions of Pinus sylvestris L. and Quercus pubescens Willd. to drought years at a xeric site in Valais, Switzerland. Dendrochronologia 23: 121-132. - doi: 10.1016/j. dendro.2005.10.002

Evans J (1984). Silviculture of broadleaved woodland. Forestry Commission Bulletin 62, HMSO, London, UK, pp. 232.

Fahrmeir L, Tutz G (1994). Multivariate statistical modeling based on generalized linear models Springer-Verlag, New York, USA, pp. 548.

Franklin RS (2013). Growth response of the alpine shrub, Linanthus pungens, to snowpack and temperature at a rock glacier site in the eastern Sierra Nevada of California, USA. Quaternary International 310: 20-33. - doi: 10.1016/j. quaint.2012.07.018

Friedrichs DA, Büntgen U, Frank DC, Esper J, Neuwirth B, Loeffler J (2009). Complex climate controls on $20^{\text {th }}$ century oak growth in central-west Germany. Tree Physiology 29: 39-51. doi: 10.1093/treephys/tpn003

Gibbs JN, Greig BJW (1997). Biotic and abiotic factors affecting the dying back of pedunculate oak Quercus robur L. Forestry 70: 399-406. doi: 10.1093/forestry/70.4.399

Grant M, Edwards M (2008). Conserving idealized landscapes: past history, public perception and future management in the New Forest (UK). Vegetation History and Archaeobotany 17: 551562. - doi: 10.1007/s00334-007-0100-3

Griggs C, De Gaetano A, Kuniholm P, Newton M (2007). A regional high-frequency reconstruction of May-June precipitation in the north Aegean from oak tree rings, A.D. 1089-1989. International Journal of Climatology 27: 1075-1089. doi: 10.1002/joc. 1459

Helama S, Läänelaid A, Raisio J, Tuomenvirta H (2009). Oak decline in Helsinki portrayed by tree-rings, climate and soil data. Plant and Soil 319: 163-174. - doi: 10.1007/s11104-008-9858-

Hendry SJ, Poole EJ, Craig I, Proudfoot JC (2005). Forest Condition 2004. Information Note FCIN075, Forestry Commission, Edinburgh, UK. [online] URL: http://www.forestry.gov.uk/PDF/ fcin075.pdf

Howard PJA, Howard DM (1984). Effects of trees on soil properties, a resampling of J.D. Ovington's plots at Bedgebury. Merlewood research and development paper no. 101, Institut of Terrestrial Ecology, Grange-over-Sands, Merlewood Research Station, pp. 14.

Hu B, Simon J, Kuster TM, Arend M, Siegwolf R, Rennenberg H (2013). Nitrogen partitioning in oak leaves depends on species, provenance, climate conditions and soil type. Plant Biology 15 : 198-209. - doi: 10.1111/plb.2012.15.issue-s1 Innes JL (1990). Assessment of tree condition. HMSO, London, UK.

Jenkins MA, Pallardy SG (1995). The influence of drought on red oak group species growth and mortality in the Missouri Ozarks. Canadian Journal of Forest Research 25: 1119-1127. - doi: 10.1139/x95-124

Kuster TM, Arend M, Bleuler P, Günthardt-Goerg MS, Schulin R (2013). Water regime and growth 
of young oak stands subjected to air-warming and drought on two different forest soils in a model ecosystem experiment. Plant Biology 15: 138-147. - doi: 10.1111/plb.2012.15.issue-s1

Leavitt SW (2002). Prospects for reconstruction of seasonal environment from tree-ring $\delta^{13} \mathrm{C}$ : baseline findings from the Great Lakes area, USA. Chemical Geology 192: 47-58. - doi: 10.1016/ S0009-2541(02)00161-4

Leblanc DC, Foster JR (1992). Predicting effects of global warming on growth and mortality of upland oak species in the Midwestern United States - a physiologically based dendroecological approach. Canadian Journal of Forest Research 22: 1739-1752. - doi: 10.1139/x92-228

Leuzinger S, Zotz G, Asshoff R, Körner C (2005) Responses of deciduous forest trees to severe drought in Central Europe. Tree Physiology 25: 641-650. - doi: 10.1093/treephys/25.6.641

Mérian P, Lebourgeois F (2011). Size-mediated climate-growth relationships in temperate forests: a multi-species analysis. Forest Ecology and Management 261: 1382-1391. - doi: 10.1016/j.foreco.2011.01.019

Mérian P, Bontemps J-D, Bergès L, Lebourgeois F (2011). Spatial variation and temporal instability in climate-growth relationships of sessile oak (Quercus petraea [Matt.] Liebl. ) under temperate conditions. Plant Ecology 212: 1855-1871. doi: 10.1007/s11258-011-9959-2

Minckler LS (1965). Pin oak (Quercus palustris Muenchh.). In: "Silvics of forest trees of the United States" (Fowells HA ed). USDA Forest Service, Washington, DC, USA, pp. 762.

Mitchell AF, Westall AW (1972). Bedgebury pinetum and forest plots. HMSO, London, UK

Morecroft MD, Bealey CE, Howells O, Rennie S, Woiwod IP (2002). Effects of drought on contrasting insect and plant species in the UK in the mid-1990s. Global Ecology and Biogeography 11: 7-22. - doi: 10.1046/j.1466-822X.2002.00 174.x

Oberhuber W, Stumböck M, Kofler W (1998). Climate-tree-growth relationships of Scots pine stands (Pinus sylvestris L.) exposed to soil dryness. Trees 13: 19-27. - doi: 10.1007/PL000097 34

Ovington JD (1953). Studies of the development of woodland conditions under different trees: I. Soils pH. Journal of Ecology 41: 13-34. - doi: $10.2307 / 2257097$
Ovington JD (1956). Studies of the development of woodland conditions under different trees. IV. The ignition loss, water, carbon and nitrogen content of the mineral soil. Journal of Ecology 44: 171-179. - doi: 10.2307/2257160

Ovington JD, Madgwick HAI (1958). The Sodium, Potassium and Phosphorus contents of tree species grown in close stands. New Phytologist 57: 273-284. - doi: 10.1111/j.1469-8137.1958. tb05316.x

Pilcher JR, Baillie MG (1980). Six modern oak chronologies from Ireland. Tree-Ring Bulletin 40: 11 .

Ray D, Morison J, Broadmeadow MS (2010). Climate change: impacts and adaptation in England's woodlands. Research Note FCRN 201, Forestry Commission, Edinburgh, UK, pp. 16. [online] URL: http://www.forestry.gov.uk/pdf/ FCRN201.pdf

R Core Team (2012). R: a language and environment for statistical computing. R Foundation for Statistical Computing, Vienna, Austria.

Robertson PA (1992). Factors affecting tree growth on three lowland sites in southern Illinois. American Midland Naturalist 128: 218236. - doi: $10.2307 / 2426456$

Rozas V (2005). Dendrochronology of pedunculate oak (Quercus robur L. ) in an old-growth pollarded woodland in northern Spain: tree-ring growth responses to climate. Annals of Forest Sciences 62: 209-218. - doi: 10.1051/forest: 2005012

Sanders T, Pitman R, Broadmeadow M (2012). Soil type modifies climate-growth response of beech in Southern Britain. In: Proceedings of the "DENDROSYMPOSIUM 2011" (Gärtner H, Rozenberg P, Montès P, Bertel O, Heinrich I, Helle G eds). Orléans (France) 11-14 May 2011. Scientific Technical Report STR11/03, Helmoltz Gemeinschaft, Potsdam, Germany.

Scharnweber T, Manthey M, Criegee C, Bauwe A, Schröder C, Wilmking M (2011). Drought matters - declining precipitation influences growth of Fagus sylvatica L. and Quercus robur L. in north-eastern Germany. Forest Ecology and Management 262: 947-961. - doi: 10.1016/j.foreco. 2011.05 .026

Schweingruber FH (1988). Tree rings: basics and applications of dendrochronology. Kluwer Academic Publishers, Dordrecht, The Netherlands, pp. 288.
Schweingruber FH (1990). Dendroecological information in pointer years and abrupt growth changes. In: "Methods of Dendrochronology, applications in the Environmental Sciences" (Cook ER, Kairiuštis L eds). Kluwer, Dordrecht, The Netherlands, pp. 227-283.

Speer JH, Grissino-Mayer HD, Orvis KH, Greenberg $\mathrm{CH}$ (2009). Climate response of five oak species in the eastern deciduous forest of the southern Appalachian Mountains, USA. Canadian Journal of Forest Research 39: 507-518. doi: 10.1139/X08-194

Spyroglou G, Chatziphilippidis G (2007). The growth simulator "Drymos" as a challenge for modelling sweet chestnut. Bulgarian Academy of Sciences, Sofia, Bulgaria, pp. 97-110.

Stokes MA, Smiley TL (1968). An introduction to tree-ring dating. University of Arizona Press, Tucson, AZ, USA, pp. 73.

Sturrock RN, Frankel SJ, Brown AV, Hennon PE, Kliejunas JT, Lewis KJ, Worrall JJ, Woods AJ (2011). Climate change and forest diseases. Plant Pathology 60: 133-149. - doi: 10.1111/j.13653059.2010.02406.x

Tardif J, Brisson J, Bergeron Y (2001). Dendroclimatic analysis of Acer saccharum, Fagus grandifolia, and Tsuga canadensis from an oldgrowth forest, southwestern Quebec. Canadian Journal of Forest Research 31: 1491-1501. - doi: 10.1139/x01-088

Thomas F, Blank R (1996). The effect of excess nitrogen and of insect defoliation on the frost hardiness of bark tissue of adult oaks. Annales des Sciences Forestières 53 (2-3): 395-406. - doi: 10.1051/forest: 19960222

Thomas FM, Blank R, Hartmann G (2002). Abiotic and biotic factors and their interactions as causes of oak decline in Central Europe. Forest Pathology 32: 277-307. - doi: 10.1046/j.14390329.2002.00291.x

Wigley TML, Briffa KR, Jones PD (1984). On the average value of correlated time series, with applications in dendroclimatology and hydrometeorology. Journal of Climate and Applied Meteorology 23: 201-213. - doi: 10.1175/15200450(1984)023<0201:OTAVOC $>2.0$. CO $; 2$

Wilson SM, Broadmeadow M, Sanders TG, Pitman R (2008). Effect of summer drought on the increment of beech trees in southern England. Quarterly Journal of Forestry 102: 9. 